\title{
Effects of resistin on porcine ovarian follicle steroidogenesis in prepubertal animals: an in vitro study
}

Agnieszka Rak-Mardyła*, Martyna Durak and Ewa Łucja Gregoraszczuk

\begin{abstract}
Background: Resistin was first reported to be an adipocyte-specific hormone, but recent studies have indicated a connection between resistin and reproductive function. However, it is not yet known if resistin is expressed by the ovary and if it can affect steroidogenesis in ovarian follicles from prepubertal pigs.

Methods: In this study, using real time PCR, immunoblotting, and ELISA, we quantified resistin expression and concentration in maturing ovarian follicles (small, 3-4 mm; medium, 4-5 mm; large, 6-7 mm) collected from prepubertal pigs. In addition, the dose-responsive effects of recombinant human resistin $(0.1,1,10$, and $100 \mathrm{ng} / \mathrm{ml})$ on steroid hormone (i.e., progesterone [P4], androstendione [A4], testosterone [T], and estradiol [E2]) secretion in culture medium and steroidogenic enzyme (i.e., CYP11A1, 3betaHSD, CYP17A1, 17betaHSD, and CYP19A1) expression in ovarian follicles were determined.

Results: We observed that resistin gene and protein expression increased significantly $(P<0.05)$ during follicular growth, with large follicles expressing the highest level of this adipokine. Recombinant resistin also increased P4, A4, and T secretion by up-regulating the steady state levels of CYP11A1, 3betaHSD, CYP17A1, and 17betaHSD. Recombinant resistin had no effects on E2 secretion and CYP19A1 expression in ovarian follicles.

Conclusion: Our results show resistin expression in ovarian follicles from prepubertal pigs for the first time. We also show that recombinant resistin stimulates steroidogenesis in ovarian follicles by increasing the expression of CYP11A1, 3betaHSD, CYP17A1, and 17betaHSD. The presence of resistin in the porcine ovary and its direct effects on steroidogenesis suggest that resistin is a new regulator of ovary function in prepubertal animals.
\end{abstract}

Keywords: Resistin, Prepubertal porcine ovarian follicle, Steroidogenesis

\section{Background}

Adipose tissue is known to control many cellular events via endocrine, paracrine, or autocrine mechanisms. Adipose tissue is rich in adipokines, secreted cytokines, and hormones that participate in several physiological and pathological processes such as food intake and metabolic control, diabetes, atherosclerosis, immunity, and reproductive function [1-3]. Leptin, adiponectin, and resistin are three well studied adipokines. Of these, resistin is a cysteine-rich C-terminal domain protein belonging to the resistin-like molecule (RELM) family

\footnotetext{
* Correspondence: agnieszka.rak@uj.edu.pl

Department of Physiology and Toxicology of Reproduction, Institute of Zoology, Jagiellonian University in Cracow, Gronostajowa 9, Cracow 30-387,
} Poland

\section{() Biomed Central}

[4]. In humans, resistin is expressed largely by adipocytes [5], and its serum level is elevated in morbidly obese individuals [6]. While the role of resistin in energy homeostasis is still unclear, previous studies have shown it to exhibit changes in expression that are similar to those of leptin $[7,8]$. For instance, fasting reduced both resistin and leptin levels, and feeding resulted in their concomitant increase $[4,8]$. Other studies have suggested a connection amongst resistin, obesity, and insulin resistance $[9,10]$, illustrating the importance of adipokines in mammalian physiology.

In recent studies, many investigators have linked resistin to reproductive function. Nogueiras et al. [11] showed resistin to increase both basal and human chorionic gonadotropin (hCG)-stimulated testosterone 
secretion dose dependently in rat testis organ cultures in vitro. They also demonstrated resistin expression in the testis to be regulated by luteinizing hormone (LH) and follicle stimulating hormone (FSH), two pituitary hormones. In female rats, resistin expression was upregulated in adipose tissue from pubertal animals [12]. Interestingly, resistin expression in the pituitary gland was found to be regulated by nutritional-, age-, and gender-specific factors, and its expression was highest in the pituitary gland of prepubertal mice [13]. Furthermore, resistin expression in adipocytes was 2-fold higher in women with polycystic ovarian syndrome (PCOS) than in healthy women [14]. Dafopoulus et al. [15] also demonstrated that serum resistin levels remained unchanged in normal cycling women, illustrating that resistin secretion from adipocytes is unaffected by fluctuations in sex steroid levels.

Recently, some data have suggested that resistin could effect on ovary function. Maillard et al. [16] demonstrated resistin expression in bovine and rat ovaries, and showed that resistin modulate granulosa cells function such as steroidogenesis and proliferation, in basal state or in response to IGF-I in vitro. This is in agreement with a study by Jones et al. [17], which reported resistin expression throughout the rat estrous cycle. Study Spicer et al. [18] showed that resistin inhibits steroidogenesis of undifferentiated (small follicles) granulosa cells and inhibits mitogenesis of differentiated (large follicles) granulosa cells collected from cattle. In human cultured theca cells, recombinant resistin triggered 17 $\alpha$-hydroxylase activity, a marker of ovarian hyperandrogenism in women with PCOS [19].

Considering data of Morash et al., 2002 [13] showing increasing resistin mRNA expression in pituitary of prepubertal mice and their suggestions that resistin could have functional implications during prepubertal time we hypothesis that resistin could be important local modulator of ovarian function during prepubertal time. To our knowledge, there is no study reporting the expression of resistin in ovarian follicles from prepubertal pigs or the effects of resistin on ovarian steroidogenesis. In the present study, we 1) investigate steady state resistin expression and protein levels in developing ovarian follicles collected from prepubertal pigs, 2) quantify resistin concentrations in these ovarian tissues, and 3) study the effects of recombinant human resistin on ovarian steroidogenesis by investigating the levels of different steroid hormones secretion and steroidogenic enzymes expression.

\section{Methods \\ Reagents}

M199 medium and phosphate buffered saline (PBS) were purchased from CytoGen, Poland. Antibiotic antimycotic solution $(100 \times)$, fetal bovine serum (FBS, heat inactivated), TRIS, sodium deoxycholate, Nonidet NP-40, sodium dodecyl sulfate (SDS), protease inhibitor (EDTAfree), dithiothreitol (DTT), Tween 20, and bromophenol blue were obtained from Sigma-Aldrich (St. Louis, MO, USA). Recombinant human resistin was obtained from Phoenix Pharmaceuticals, Inc. (Burlingame, CA, USA). Human resistin was utilized in this experiment because porcine resistin was not readily available at the onset of the experiment. Human resistin differs from porcine resistin only by one amino acids [20].

\section{Sample collection}

Porcine ovaries were collected from prepubertal (45 months of age) crossbred gilts (Large White and Polish Landrace) at a local abattoir. Approximately $15 \mathrm{~min}$ elapsed from slaughter to ovary collection. Small (SF, 3-4 mm; $n=6$ ), medium (MF, $4-5 \mathrm{~mm} ; n=6$ ) and large (LF, 6-7 $\mathrm{mm} ; n=6$ ) follicles were obtained from animals, as described previously [21]. For each experiment described below, six ovaries from three different animals were selected. Since each ovary yielded four to six follicles, the total number of follicles for each preparation varied between 24 and 36. This approach was used to minimize experimental variation throughout the study. Follicular fluid was also aspirated from follicles using a sterile needle and syringe.

\section{Experimental procedure}

In Experiment 1 analysis of resistin gene expression in ovarian follicles was determined. For RNA isolation, whole ovarian follicles after excision of ovary and follicular fluid collected, were immediately frozen in liquid nitrogen and then stored at $-70^{\circ} \mathrm{C}$.

Experiment 2 quantified resistin expression in whole ovarian follicles, and determined resistin concentrations protein in follicular fluid. SFs, MFs, and LFs were homogenized twice in ice-cold lysis buffer $(50 \mathrm{mM}$ Tris- $\mathrm{HCl}\left(\mathrm{pH} \mathrm{7.5)}\right.$ at $22^{\circ} \mathrm{C}$ containing $100 \mathrm{mM} \mathrm{NaCl}$, $0.5 \%$ sodium deoxycholate [wt $/ \mathrm{vol}], 0.5 \% \mathrm{NP}-40[\mathrm{vol} / \mathrm{vol}]$, $0.5 \% \mathrm{SDS}[\mathrm{wt} / \mathrm{vol}]$, and protease inhibitor). Lysates were cleared by centrifugation at $15,000 \times g$ at $4^{\circ} \mathrm{C}$ for $30 \mathrm{~min}$, and protein content was determined by a protein assay (Bio-Rad Laboratories, Munchen, Germany) using bovine serum albumin (BSA) as a standard. All samples were stored at $-20^{\circ} \mathrm{C}$ until further analysis.

Experiment 3 investigated the short-term effects of recombinant human resistin on steroid hormone (i.e., P4, $\mathrm{A} 4, \mathrm{~T}$, and E2) secretion and steroidogenic enzyme (i.e., CYP11A1, 3ßHSD, CYP17A1, 17ßHSD, and CYP19A1) expression. After isolation, follicles were cut, using small scissors, to facilitate penetration of the compounds into the tissue and removal oocytes and follicular fluids. Whole ovarian follicles, including theca and granulosa 
cells were cut to small pieces $(2-3 \mathrm{~mm})$ and individually cultured in 24-well plates with M199 medium supplemented with 5\% FBS [vol/vol] and increasing concentrations of resistin $(0.1,1,10$, and $100 \mathrm{ng} / \mathrm{ml})$ at $37^{\circ} \mathrm{C}$ in a humidified atmosphere containing $5 \% \mathrm{CO}_{2}$ [vol/vol]. These doses were chosen based on a previously published study [12] and on Experiment 2. After 24 h, conditioned culture media were collected and stored at $-20^{\circ} \mathrm{C}$ for steroid hormone determination. Cultured ovarian follicles was homogenized twice in ice-cold lysis buffer and centrifuged at $15,000 \times g$ at $4^{\circ} \mathrm{C}$ for $30 \mathrm{~min}$. Protein content was determined as described above. All samples were stored at $-20^{\circ} \mathrm{C}$ until further analysis. It should be noted that this in vitro model was previously used to study the function of leptin in the porcine ovary [22]. Based on our experience, this model mimics ovarian physiology more closely than co-cultures of different ovarian cells or cell lines.

Experiment 4 examined the short-term effects of recombinant resistin on steroidogenic enzyme (i.e., CYP11A1, HSD3B1 [3BHSD], CYP17A1, HSD17B1 [17ßHSD], and CYP19A1) mRNA expression. This experiment was similar to Experiment 3, except that cultured ovarian follicles was frozen immediately in liquid nitrogen and then stored at $-70^{\circ} \mathrm{C}$ for RNA isolation.

\section{Total RNA isolation and cDNA synthesis}

Isolation of total RNA, including a 15 min treatment with DNase I, was carried out with the High Pure RNA Tissue kit (Roche Applied Science, Mannheim, Germany). RNA concentrations were determined by spectrophotometry at 260 and $280 \mathrm{~nm}$ (BioPhotometer Plus, Eppendorf, Germany), and $1 \mu \mathrm{g}$ of RNA was used for reverse transcription. Reverse transcription was performed using the Transcriptor First Strand cDNA Synthesis kit (Roche Applied Science) in combination with $50 \mathrm{pmol} / \mu \mathrm{L}$ anchored-oligo $(\mathrm{dT})_{18}$ primer and 600 $\mathrm{pmol} / \mu \mathrm{L}$ random hexamer primers. The reverse transcription reaction was incubated at $25^{\circ} \mathrm{C}$ for $10 \mathrm{~min}$. This was followed by two subsequent incubations at $50^{\circ} \mathrm{C}$ for $60 \mathrm{~min}$ and $85^{\circ} \mathrm{C}$ for $5 \mathrm{~min}$, and then cooling to $4^{\circ} \mathrm{C}$. Samples were stored at $-20^{\circ} \mathrm{C}$ until further analysis.

\section{Real time PCR}

Real time PCR analyses were performed using either StepOne Real-Time PCR (Applied Biosystems, Carlsbad, CA, USA) or LightCycler Nano SW1.0 Real-Time PCR (Roche Diagnostics, Indianapolis, IN, USA) systems. TaqMan Gene Expression assays were used to quantify mRNA expression (Table 1). GAPDH was used as an internal control. Quantitative PCR was performed with 100 ng cDNA, $1 \mu \mathrm{L}$ TaqMan Gene Expression primers, and $10 \mu \mathrm{L}$ TaqMan PCR master mix (Applied Biosystems) in a final reaction volume of $20 \mu \mathrm{L}$. After a 2 min incubation at $50^{\circ} \mathrm{C}$, thermal cycling conditions were $10 \mathrm{~min}$ at $95^{\circ} \mathrm{C}$, followed by 40 cycles of $15 \mathrm{sec}$ at $95^{\circ} \mathrm{C}$ and $1 \mathrm{~min}$ at $60^{\circ} \mathrm{C}$ to determine the cycle threshold number $\left(C_{\mathrm{t}}\right)$ for quantitative measurement. Data were analyzed using the comparative threshold cycle $(\mathrm{Ct})$ method and expressed as a ratio of target gene to GAPDH.

\section{Immunoblot analysis}

Immunoblotting was performed as previously described [21]. Briefly, equal amounts of lysate $(\sim 30-50 \mu \mathrm{g}$ protein/ lane) were separated on 10-15\% T SDS-polyacrylamide gels. Separated proteins were transferred onto nitrocellulose membranes and blocked with 5\% non-fat dry milk in Tris-buffered saline containing $0.1 \%$ Tween-20 [vol/vol] (TBS-T). Membranes were then incubated overnight at $4^{\circ} \mathrm{C}$ with anti-resistin (cat. \#sc-17575), anti-CYP11A1 (cat. \#sc-18040), anti-3ßHSD (cat. \#sc-30820), anti-CYP17A1 (cat. \#sc-46084), anti-17ßHSD (cat. \#sc-26963), or antiCYP19A1 (cat. \#sc-14244) antibodies (1:200, Santa Cruz Biotechnology, Inc., Santa Cruz, CA, USA) on a shaker. After washing with TBS-T, membranes were incubated with a horseradish peroxidase-conjugated secondary antibody (Santa Cruz Biotechnology, Inc.). Immune complexes were detected by chemiluminescence (ECL) using Western Blotting Luminol reagent (Santa Cruz Biotechnology, Inc.) and visualized with a Chemidoc $^{\mathrm{TM}} \mathrm{XRS}^{+}$ system (Bio-Rad Laboratories). Proteins of interest were quantified using Image $\mathrm{Lab}^{\text {тм }} 2.0$ software (Bio-Rad Laboratories). An anti- $\beta$-actin antibody (1:3000) was used as a loading control (Cat. \#A5316, Sigma-Aldrich).

Table 1 Characteristic of investigated gens

\begin{tabular}{|c|c|c|c|}
\hline Gene symbol & Gene name & Catalog number & Reference sequence \\
\hline RETN & resistin & Ss03381389_u1 & NM_213783.1 \\
\hline CYP11A1 & cytochrome P450, family 11, subfamily A, polypeptide 1 & Ss03384849_u1 & NM_214427.1 \\
\hline HSD3B1 (3ßHSD) & hydroxy-delta-5-steroid dehydrogenase, 3 beta- and steroid delta-isomerase 1 & Ss03391752_m1 & NM_001004049.1 \\
\hline CYP17A1 (CYP17) & cytochrome P450 17A1 & Ss03394947_m1 & NM_214428.1 \\
\hline HSD17B1 (17BHSD) & hydroxysteroid (17-beta) dehydrogenase 1 & Ss04245959_g1 & NM_001128472.1 \\
\hline CYP19A1 (CYP19) & cytochrome P450 19A1 & Ss03384876_u1 & NM_214429.1 \\
\hline GAPDH & glyceraldehyde-3-phosphate dehydrogenase & Ss03375629_u1 & NM_001206359.1 \\
\hline
\end{tabular}

TaqMan gene expression assays were used to quantify mRNA expression. 


\section{Resistin ELISA}

A commercially available human resistin enzyme-linked immunosorbent assay (ELISA) (cat. \# EIA-4945, DRG International, Inc., Mountainside, NJ, USA) was used to quantify resistin concentrations in ovarian follicles lysates and follicular fluid. Samples were run in triplicate within the same assay. The sensitivity of the resistin assay was $0.016-1 \mathrm{ng} / \mathrm{ml}$, and the intra- and interexperimental coefficients of variation were $10 \%$ and $15 \%$, respectively.

\section{Hormone ELISAs}

Steroid hormone (i.e., P4, A4, T, and E2) levels were determined in conditioned culture media using commercially available ELISA kits (cat. \#s EIA-1561, EIA-3265, EIA-1559, and EIA-2693, DRG Diagnostic, Marburg, Germany). E2 levels were also measured in follicular fluid, and samples were run in duplicate within this assay. The sensitivity of each assay was $0.045 \mathrm{ng} / \mathrm{ml}$ for $\mathrm{P} 4,0.019-10 \mathrm{ng} / \mathrm{ml}$ for $\mathrm{A} 4,0.083-16 \mathrm{ng} / \mathrm{ml}$ for $\mathrm{T}$, and $9.7-2000 \mathrm{pg} / \mathrm{ml}$ for E2. The intra- and inter-experimental coefficients of variation were $6.99 \%$ and $4.34 \%$ for P4, $5.6 \%$ and $12.1 \%$ for A4, 3.28\% and $6.71 \%$ for $\mathrm{T}$, and $2.71 \%$ and $6.72 \%$ for E2, respectively. Cross-reactivity between $\mathrm{T}$ and $\mathrm{A} 4$ was $0.9 \%$, and between $\mathrm{T}$ and $\mathrm{E} 2$ was $<0.1 \%$. Cross-reactivity amongst E2, A4, and $\mathrm{T}$ was $0 \%$, but crossreactivity with estrone was $0.2 \%$ based on specification sheets provided by the manufacturer. All other samples were run in quadruplicate within each assay.

\section{Statistical analysis}

Real time PCR, Western blot and ELISA experiments were performed three independent times. In each experiment six ovaries from three different animals were selected. Data were plotted as mean \pm S.E.M. All remaining data were shown as the mean \pm S.D. Statistical analyses were performed using GraphPad Prism 5 software (La Jolla, CA, USA). Data were analyzed using a one-way analysis of variance (ANOVA) test, followed by Tukey's honestly significant difference (HSD) test. Statistical significance is indicated by different letters or * $P<0.05$.

\section{Results}

Resistin expression and concentration in ovarian follicles Real time PCR experiments showed that ovarian follicles obtained from prepubertal pigs expressed resistin. Resistin expression in ovarian follicles increased significantly with follicular growth, with LFs expressing the highest level of this adipokine (1.5-fold increase compared to SFs and 1.2-fold increase compared to MFs, $P<0.05)$ (Figure 1).

To confirm real time PCR results, immunoblotting was performed using SF, MF, and LF lysates and follicular fluid. The steady state level of resistin increased significantly in maturing follicles as well as in follicular fluid (Figure 1B). In agreement with the data shown in Figure 1A, resistin was highest in both LF lysate and follicular fluid (2-fold for SFs and 1.8-fold for MFs in follicular fluid, and 1.8 fold to SFs and 1.6 fold to MFs in ovarian follicles tissue) $(P<0.05)$. For positive control we used porcine white adipose tissue (Figure 1C).

Resistin levels were higher in SFs $(0.27 \mathrm{ng} / \mu \mathrm{g}$ protein), MFs $(0.29 \mathrm{ng} / \mu \mathrm{l}$ protein), and LFs $(0.411 \mathrm{ng} / \mu \mathrm{g}$ protein $)$ than in follicular fluid collected from corresponding follicles $(0.03,0.03$, and $0.106 \mathrm{ng} / \mu \mathrm{g}$ protein, respectively) (Figure 1D, $P<0.05$ ). The increase in resistin during follicular growth also correlated with a steady increase in estradiol in follicular fluid collected from SFs, MFs, and LFs $(3.87,7.22$, and $9.58 \mathrm{pg} / \mathrm{ml}$, respectively) (Figure 1E).

\section{Effects of resistin on the secretion of steroid hormones}

Basal steroid secretion in conditioned culture media collected from SFs was $6.2 \mathrm{ng} / \mathrm{ml}$ for P4, $3.3 \mathrm{ng} / \mathrm{ml}$ for A4, $7.5 \mathrm{ng} / \mathrm{ml}$ for $\mathrm{T}$, and $8.7 \mathrm{ng} / \mathrm{ml}$ for E2. Recombinant resistin at increasing concentrations stimulated P4 (8.9, 9.2, 8, and $7.6 \mathrm{ng} / \mathrm{ml}$ at $0.1,1,10$, and $100 \mathrm{ng} / \mathrm{ml}$ doses of resistin, respectively) and $\mathrm{T}(10.9,11.9,9.8$, and $10.7 \mathrm{ng} / \mathrm{ml}$ at $0.1,1,10$ and $100 \mathrm{ng} / \mathrm{ml}$ doses of resistin, respectively) secretion. Both A4 and E2 in SF conditioned culture media remained unchanged by recombinant resistin (Figure $2 \mathrm{~A}, P<0.05$ ).

Basal steroid secretion in MF conditioned culture media was $8.7 \mathrm{ng} / \mathrm{ml}$ for $\mathrm{P} 4,2.7 \mathrm{ng} / \mathrm{ml}$ for $\mathrm{A} 4,8.6 \mathrm{ng} / \mathrm{ml}$ for $\mathrm{T}$, and $9.5 \mathrm{ng} / \mathrm{ml}$ for E2. Recombinant resistin at increasing concentrations stimulated P4 (10.1, 11.8, and $11.8 \mathrm{ng} / \mathrm{ml}$, respectively), A4 $(3.9,4.2$, and $5.9 \mathrm{ng} / \mathrm{ml}$, respectively), and $\mathrm{T}(10.8,13.7,13.6$, and $11.4 \mathrm{ng} / \mathrm{ml}$, respectively) secretion. Recombinant resistin had no effect on $\mathrm{E} 2$ secretion (Figure $2 \mathrm{~B} ; \mathrm{P}<0.05$ ).

Finally, basal steroid secretion in LF conditioned culture media was $10.8 \mathrm{ng} / \mathrm{ml}$ for $\mathrm{P} 4,3.1 \mathrm{ng} / \mathrm{ml}$ for A4, $13.1 \mathrm{ng} / \mathrm{ml}$ for $\mathrm{T}$, and $11.4 \mathrm{ng} / \mathrm{ml}$ for E2. Recombinant resistin at increasing concentrations up-regulated $\mathrm{P} 4$ (12.2, 11.7, and $12.8 \mathrm{ng} / \mathrm{ml}$, respectively), A4 (4, 4.5, 4.3, and $4.3 \mathrm{ng} / \mathrm{ml}$, respectively), and $\mathrm{T}(14.3,14.1,14.8$, and $15.9 \mathrm{ng} / \mathrm{ml}$, respectively) secretion. Likewise, E2 secretion remained unchanged by recombinant resistin in LF conditioned culture media (Figure $2 \mathrm{C}, P<0.05$ ).

\section{Effects of recombinant human resistin on the mRNA expression of steroidogenic enzymes}

To investigate the effects of increasing concentrations of recombinant resistin $(0.1,1,10$, and $100 \mathrm{ng} / \mathrm{ml})$ on steroidogenic enzyme mRNA expression, real time PCR was performed on total RNAs isolated from SFs, MFs, and LFs. The expression of each gene (i.e., 


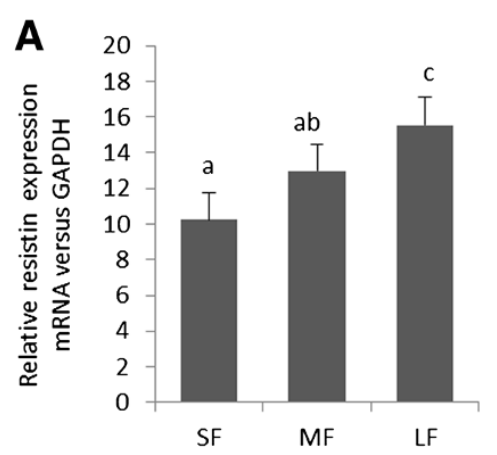

B
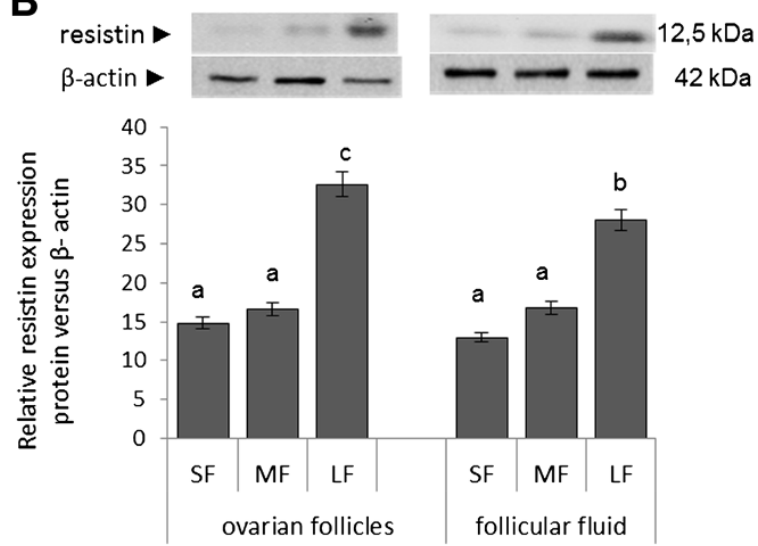

c

White adipose tissue

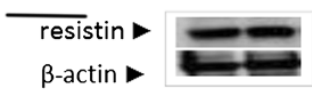

D

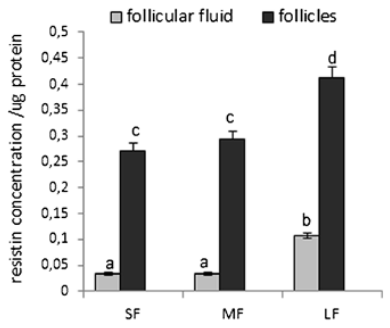

E

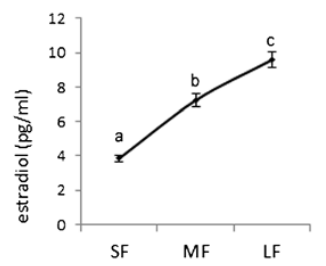

Figure 1 Resistin expression and concentration in ovarian follicles. Resistin expression and concentration in ovarian follicles collected from prepubertal animals; $\mathbf{A}$ ) The ratio of resistin gene intensity to GAPDH intensity was used to represent the abundance of resistin mRNA in the ovarian follicles. B) The amount of protein $(50 \mu \mathrm{g})$ in every sample was checked by immunoblot using anti- $\beta$-actin antibody. Upper panels: representative blots of tissue homogenates resolved by $15 \%$ SDS-PAGE, immunoblotted with resistin antibodies and reprobed with $\beta$-actin antiserum. Lower panels: results of densitometric quantification of bands. The data are expressed as the mean \pm SEM of rations relative to GAPDH or to $\beta$-actin. C) For positive control we used porcine white adipose tissue. D) Concentrations of resistin in follicular fluid and ovarian tissue. Different letters indicate statistically significant differences among groups $(P<0.05)$. E) Estradiol concentrations in follicular fluid.

CYP11A1, 3BHSD, CYP17A1, 17BHSD, and CYP19A1) was normalized to the expression of GAPDH. Recombinant resistin at all investigated doses stimulated significantly CYP11A1 and $3 \beta H S D$ expression in SFs $(P<0.05)$. Resistin at 1,10 , and $100 \mathrm{ng} / \mathrm{ml}$ also increased $17 \beta H S D$ expression in SFs, but no significant changes in expression were observed for CYP17A1 and CYP19 (Figure 3A).

Likewise, the expression of CYP11A1 (at 0.1, 1, 10, and $100 \mathrm{ng} / \mathrm{ml}$ of resistin), $3 \beta H S D$ (at $0.1,1$, and $10 \mathrm{ng} / \mathrm{ml}$ of resistin), CYP17A1 (at $0.1,1,10$, and $100 \mathrm{ng} / \mathrm{ml}$ of resistin), and $17 \beta H S D$ (at 1,10 , and $100 \mathrm{ng} / \mathrm{ml}$ of resistin) increased significantly in MFs after the addition of recombinant resistin (Figure 3B, $P<0.05$ ). Recombinant resistin had no effect on CYP19 expression.

Recombinant resistin also up-regulated the expression of CYP11A1 (at $0.1,1,10$, and $100 \mathrm{ng} / \mathrm{ml}$ of resistin), $3 \beta H S D$ (at 1,10 , and $100 \mathrm{ng} / \mathrm{ml}$ of resistin), CYP17A1 (at $100 \mathrm{ng} / \mathrm{ml}$ of resistin), and $17 \beta H S D$ (at $0.1,1,10$, and $100 \mathrm{ng} / \mathrm{ml}$ of resistin) in LFs (Figure $3 C, P<0.05$ ); however, CYP19 expression in LFs remained unchanged by recombinant resistin.

\section{Effects of recombinant human resistin on the protein expression of steroidogenic enzymes}

The steady state levels of CYP11A1, 33HSD, CYP17A1, $17 \beta H S D$, and CYP19 were investigated in developing ovarian follicles incubated with recombinant resistin, and representative immunoblots from this experiment are shown in Figure 4. Proteins were densitometrically scanned and normalized against $\beta$-actin (Figure 5). Resistin at different concentrations up-regulated the

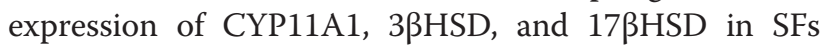
(Figure 5A, $P<0.05$ ).

Resistin at increasing concentrations also stimulated CYP11A1, 3ßHSD, CYP17A1, and 17ßHSD in MFs (Figure $5 \mathrm{~B}, P<0.05$ ).

Significant differences were also observed in the steady state levels of CYP11A1, 3ßHSD, CYP17A1, and $17 \beta$ HSD following incubation of LFs with increasing 


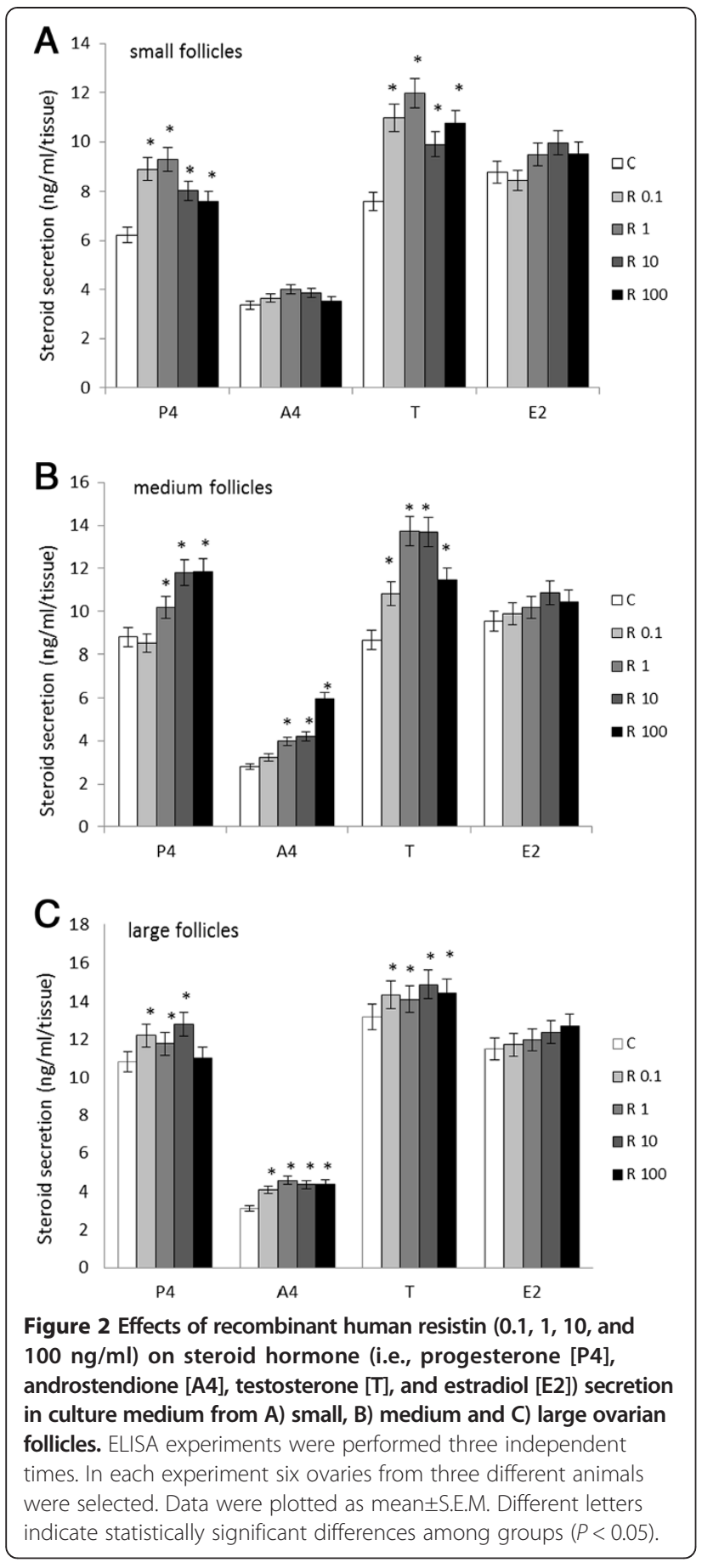

concentrations of resistin; however, CYP19 remained unchanged by recombinant resistin (Figure $5 \mathrm{C}$ ).

\section{Discussion}

Female puberty, the estrous cycle, and reproduction are known to be regulated by the hypothalamic-pituitary axis which is comprised of many critical hormones. Many studies have shown that locally produced factors such as steroids, growth factors, and peptides regulate
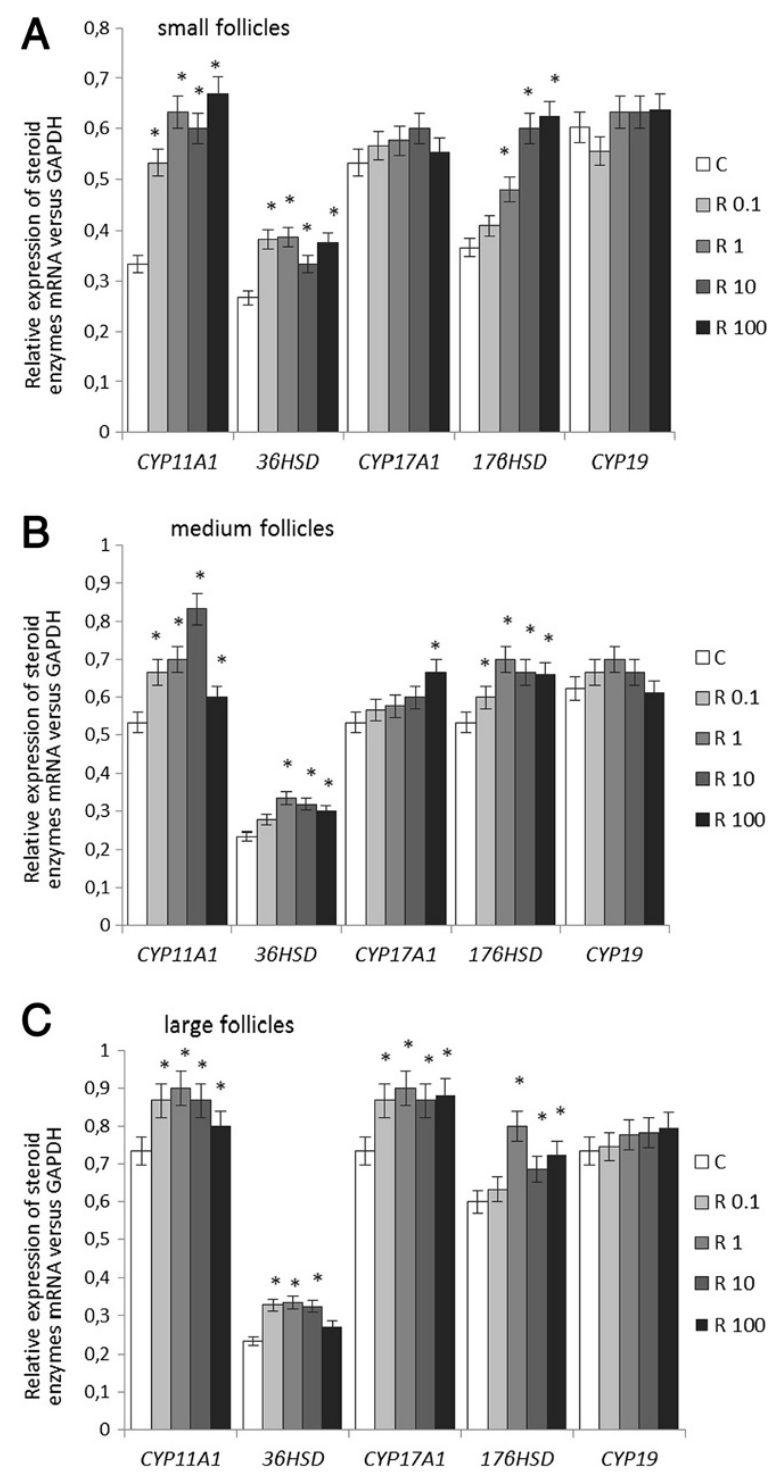

Figure 3 Effects of recombinant human resistin $(0.1,1,10$, and $100 \mathrm{ng} / \mathrm{ml}$ ) on the mRNA expression of steroidogenic enzymes (i.e., CYP11A1, 3BHSD, CYP17A1, 17ßHSD, and CYP19A1) in A) small, B) medium and C) large ovarian follicles. The expression of mRNA has been determined by real time-PCR. The expression of each gene was normalized to the expression of GAPDH. Real time PCR experiments were performed three independent times. In each experiment six ovaries from three different animals were selected. Data were plotted as mean \pm S.E.M. Statistical significance is indicated by * $P<0.05$.

the development of ovarian follicles and the onset of puberty and/or ovulation [23]. Other studies have reported the expression of leptin, an adipose tissue hormone, in the ovary [24], where it was found to regulate ovarian function during puberty [25] and the estrous cycle in humans, mice, rats, pigs, and cows [26-28]. Unfortunately, the role of resistin in ovarian follicle development is currently unknown. The present study 


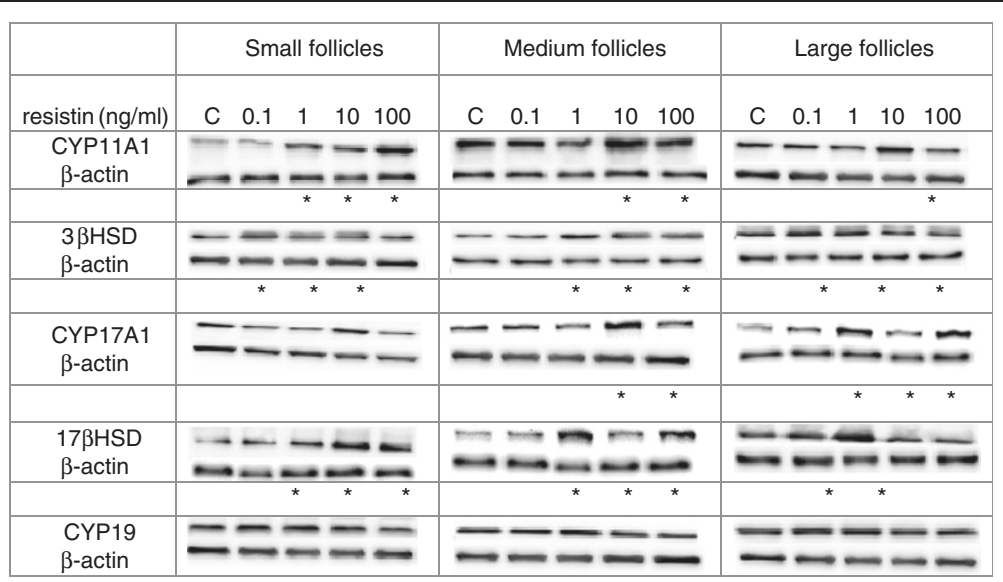

Figure 4 Effects of recombinant human resistin. $(0.1,1,10$, and $100 \mathrm{ng} / \mathrm{ml})$ on the protein expression of steroidogenic enzymes CYP11A1, 3ßHSD, CYP17A1, 17ßHSD, and CYP19 small, medium and large ovarian follicles. The representative samples of western blots are shown in the panels. Western blot experiments were repeated three independent times using samples from three different animals. Data were plotted as mean \pm S.E.M. Statistical significance is indicated by $* P<0.05$.

reports for the first time the expression of resistin in porcine prepubertal ovarian follicles. Using real time PCR, Western blot, and ELISA, we show differences in the expression and concentration of resistin in follicular fluid collected from SFs, MFs, and LFs. In ovarian follicles collected from prepubertal animals, a $\sim 1.6$-fold increase in expression and a $\sim 2$-fold increase in protein were observed in LFs, correlating with resistin levels in follicular fluid and follicular tissue. Our results show that resistin expression in the prepubertal ovary also correlated with an increase in estradiol in follicular fluid. Puberty is characterized by increasing concentrations of estradiol, driven by increasing concentrations of pituitary gonadotropins which are, in turn, regulated by gonadotropinreleasing hormone that is released by hypothalamic neurons [29]. Chen et al. [30] used 3 T3-L1 adipocytes to show that estradiol stimulates resistin expression in a dose- and time-dependent manner. This is in agreement with other studies that showed androgens [31] and growth hormones [32] to increase during puberty, and to stimulate the expression of resistin. Additionally, a strong link between resistin and development has been found in rats, where resistin expression was highest at puberty only to decrease in adipose tissue [12]. Moreover, $\mathrm{Li}$ et al. [33] showed human resistin levels to decrease with age and puberty in both genders.

In agreement with our results, Maillard et al. [16] showed resistin expression in the bovine and rat ovary. For instance, they demonstrated resistin to be widely expressed in SFs $(<6 \mathrm{~mm})$ and LFs $(>6 \mathrm{~mm})$, corpora lutea, and oocytes as well as in cumulus, theca, and granulosa cells. Interestingly, resistin expression was approximately 5 -fold higher in freshly isolated granulosa cells than in cells that were cultured in vitro. Within the ovary, resistin expression was detected in the corpus luteum, oocyte, theca, and granulosa cells [16]. Jones et al. [17] also showed resistin expression in the rat ovary. In an earlier study, Dai et al. [34] cloned and characterized porcine resistin, and they found serum resistin to circulate as a dimer and a trimer and they also suggest that pig may be a suitable animal model for studying the function of resistin in human insulin resistance [34].

The in vitro effects of recombinant resistin on steroid hormone secretion and steroid enzyme expression were also interesting as they may represent a unique mechanism of resistin action in the prepubertal ovary. Our results showed that recombinant resistin increased $\mathrm{P} 4$, $\mathrm{A} 4$, and $\mathrm{T}$ secretion in conditioned culture media from MFs and LFs; however, E2 secretion was unaffected. These results were confirmed by additional experiments that showed recombinant resistin to affect the steady state levels of CYP11A1, 3ßHSD, CYP17A1, and $17 \beta$ HSD. These findings are also consistent with a previous in vitro study by Munir et al. [19] that showed resistin to increase androgen production in cultured human theca interna tissue from small antral follicles (8-9 $\mathrm{mm}$ ) normal cycling premenopausal women. They also observed that resistin $(1 \mathrm{ng} / \mathrm{ml})$ or a combination of resistin, forskolin, and insulin, enhanced CYP17 expression and $17 \alpha$-hydroxylase activity (a marker of ovarian hyperandrogenism in PCOS women) [19]. In our study we used porcine whole ovarian follicles collected from prepubertal animals. Prenatal, perinatal, or postnatal height androgen exposure in many species such as in monkeys [35], sheep [36], rats [37], and mice [38] can induce many symptoms characteristic of PCOS. Nevertheless, data on the effects of resistin on ovarian steroidogenesis are contradictory. In cultured rat granulosa 


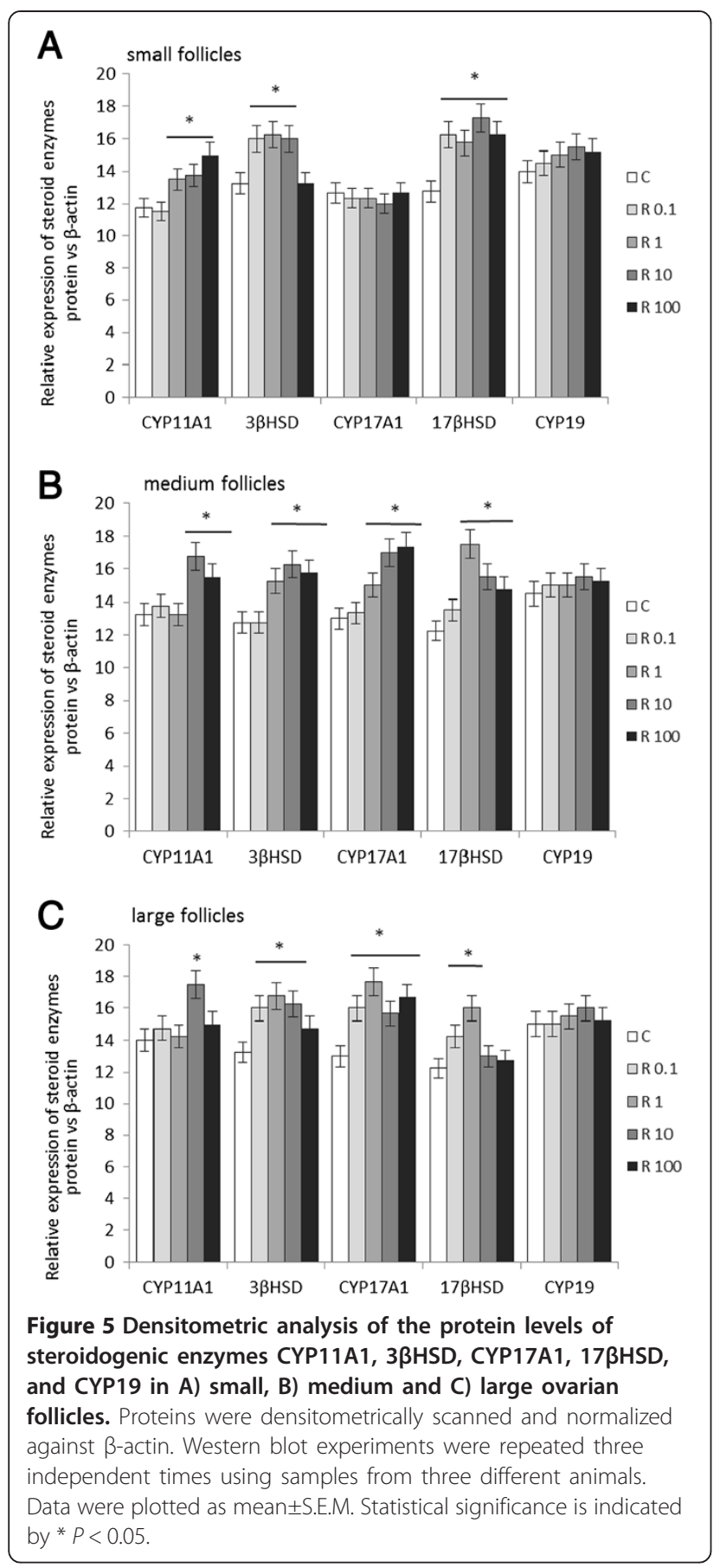

cells, P4 secretion increased following treatment with a physiological dose of resistin $(10 \mathrm{ng} / \mathrm{ml})$ with no effects on E2, while resistin decreased both $\mathrm{P} 4$ and E2 production by granulosa cells isolated from the cow ovary [16]. These contradictory findings led the authors to conclude that resistin is regulated differently across species [16]. Furthermore, Spicer et al. [18] showed that resistin inhibited steroidogenesis in theca and granulosa cells from small (1-5 $\mathrm{mm})$ and large $(8-22 \mathrm{~mm})$ cattle follicles.
Taken collectively, our data showed that resistin expression increased during follicular development. We also showed that recombinant resistin stimulated androgen secretion from ovarian follicles by up-regulating the steady state levels of CYP11A1, 3ßHSD, CYP17A1, and $17 \beta$ HSD. Lastly, recombinant resistin had no effects on E2 secretion and CYP19A1 expression in porcine prepubertal ovarian follicles.

\section{Conclusion}

In this study, we demonstrated resistin expression in ovarian follicles obtained from prepubertal pigs. This expression increased during follicular development, with LFs expressing the highest level of the adipokine. We also demonstrated that recombinant resistin affected ovarian steroidogenesis by stimulating androgen production and steroid enzyme expression. In conclusion, the presence of resistin in the porcine ovary and its direct effects on steroidogenesis suggest that resistin may be a new regulator of ovary function in prepubertal animals. However, additional studies on in vivo model are necessary to confirm this hypothesis.

\section{Abbreviations}

A4: Androstendione; CYP11A1: Cytochrome P450, family 11, subfamily A, polypeptide 1; CYP17: Cytochrome P-450c17a; CYP17A1: Cytochrome P450, family 17, subfamily A, polypeptide 1; CYP19: Cytochrome P450 aromatase; CYP19A1: Cytochrome P450, family 19, subfamily A, polypeptide 1; E2: Estradiol; ELISA: Enzyme-linked immunosorbent assay; FSH: Follicle stimulating hormone; GAPDH: Glyceraldehyde-3-phosphate dehydrogenase;

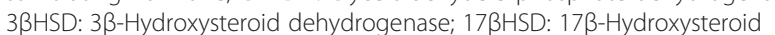
dehydrogenase; HSD3B1: Hydroxy- $\delta$-5-steroid dehydrogenase, $3 \beta$ - and steroid $\delta$-isomerase 1; HSD17B1: Hydroxysteroid (17- $\beta$ ) dehydrogenase 1; LF: Large follicle; LH: Luteinizing hormone; MF: Medium follicle; P4: Progesterone; R: Resistin; SF: Small follicle; T: Testosteron.

\section{Competing interests}

The authors declare that they have no competing interests.

\section{Authors' contributions}

AR-M contributed substantially to the conception and design of this study, performed experiments, and interpreted all data. MD performed the ELISA experiments. ELG drafted and revised the manuscript, evaluating it critically for important intellectual content. All authors read and approved the final manuscript.

\section{Acknowledgments}

This study was supported by the Budget of Sciences as a "luventus Plus" programme (Project 0343/POI/2010/70, 2010-2011). Dr Agnieszka Rak-Mardy ta was supported by the Foundation for Polish Science. The authors wish to thank Barbara Kędziora for her technical support.

Received: 30 October 2012 Accepted: 27 February 2013 Published: 17 May 2013

\section{References}

1. Otero M, Lago R, Lago F, Casanueva FF, Dieguez C, Gómez-Reino JJ, Gualillo O: Leptin, from fat to inflammation: old questions and new insights. FEBS Lett 2005, 579:295-301.

2. Trayhurn P, Wood IS: Adipokines: inflammation and the pleiotropic role of white adipose tissue. Br J Nutri 2004, 92:347-355.

3. Trayhurn P, Wood IS: Signalling role of adipose tissue: adipokines and inflammation in obesity. Biochem Soc Trans 2005, 33:1078-1081. 
4. Steppan CM, Brown EJ, Wright CM, Bhat S, Banerjee RR, Dai CY, Enders GH, Silberg DG, Wen X, Wu GD, Lazar MA: A family of tissue specific resistinlike molecules. Proc Natl Acad Sci U S A 2001, 98:502-506.

5. McTernan PG, McTernan CL, Chetty R, Jenner K, Fisher FM, Lauer MN, Crocker J, Barnett AH, Kumar S: Increased resistin gene and protein expression in human abdominal adipose tissue. J Clin Endocrinol Metab 2002, 87:2407-2410.

6. Savage DB, Sewter CP, Klenk ES, Segal DG, Vidal-Puig A, Considine RV O'Rahilly S: Resistin/Fizz3 expression in relation to obesity and peroxisome proliferator-activated receptor-gamma action in humans. Diabetes 2001, 50:2199-2202

7. Kim KH, Zhao L, Moon Y, Kang C, Sul HS: Dominant inhibitory adipocyte-specific secretory factor (ADSF)/resistin enhances adipogenesis and improves insulin sensitivity. Proc Natl Acad Sci U S A 2004, 101:6780-6785.

8. Rajala MW, Qi Y, Patel HR, Takahashi N, Banerjee R, Pajvani UB, Sinha MK, Gingerich RL, Scherer PE, Ahima RS: Regulation of resistin expression and circulating levels in obesity, diabetes, and fasting. Diabetes 2004, 53:1671-1679.

9. Steppan CM, Bailey ST, Bhat S, Brown EJ, Banerjee RR, Wright CM, Patek HR Ahima RS, Lazar MA: The hormone resistin links obesity to diabetes. Nature 2001, 409:307-312.

10. Lazar MA: Resistin- and obesity-associated metabolic diseases. Horm Metab Res 2007, 39:710-716.

11. Nogueiras R, Barreiro ML, Caminos JE, Gaytán F, Suominen JS, Navarro VM, Casanueva FF, Aguilar E, Toppari J, Diéguez C, Tena-Sempere M: Novel expression of resistin in rat testis: functional role and regulation by nutritional status and hormonal factors. J Cell Sci 2004 117:3247-3257.

12. Nogueiras R, Gualillo O, Caminos JE, Casanueva FF, Diéguez CR: Regulation of resistin by gonadal, thyroid hormone, and nutritional status. Obes Res 2003, 11:408-414.

13. Morash BA, Ur E, Wiesner G, Roy J, Willkinson M: Pituitary resistin gene expression: effects of age, gender and obesity. Neuroendocrinology 2004, 79:149-156.

14. Seow KM, Juan CC, Wu LY, Hsu YP, Yang WM, Tsai YL, Hwang JL, Ho LT: Serum and adipocyte resistin in polycystic ovary syndrome with insulin resistance. Hum Reprod 2004, 19:48-53.

15. Dafopoulos K, Sourlas D, Kallitsaris A, Pournaras S, Messinis IE: Blood ghrelin, resistin, and adiponectin concentrations during the normal menstrual cycle. Fertil Steril 2009, 92:1389-1394.

16. Maillard V, Froment P, Ramé C, Uzbekova S, Elis S, Dupont J: Expression and effect of resistin on bovine and rat granulosa cell steroidogenesis and proliferation. Reproduction 2011, 141:467-479

17. Jones AM, Rodgers J, Antibus D, Knoop A, Bruot B, Marcinkiewicz J: Relative ovarian resistin expression in normal cycling rats and rats with cystic ovaries. Biol Reprod 2009, 81(1):532.

18. Spicer $\amalg$, Schreiber NB, Lagaly DV, Aad PY, Douthit LB, Grado-Ahuir JA: Effect of resistin on granulosa and theca cell function in cattle. Anim Reprod Sci 2011, 124:19-27.

19. Munir I, Yen HW, Baruth T, Tarkowski R, Azziz R, Magoffin DA, Jakimiuk AJ: Resistin stimulation of 17alpha-hydroxylase activity in ovarian theca cells in vitro: relevance to polycystic ovary syndrome. J Clin Endocrinol Metab 2005, 90:4852-4857.

20. Adeghate E: An update on the biology and physiology of resistin. Cell Mol Life Sci 2004, 61:2485-2496.

21. Rak-Mardyla A, Gregoraszczuk EL: Expression of ghrelin and its receptor in porcine ovarian follicles collected from prepubertal and estrous cycle animals. J Physiol Pharmacol 2012, 63:195-199.

22. Gregoraszczuk EL, Rak A, Wójtowicz A, Ptak A, Wojciechowicz T, Nowak KW: $\mathrm{GH}$ and IGF-I increase leptin receptor expression in prepubertal pig ovaries: the role of leptin in steroid secretion and cell apoptosis. Acta Vet Hung 2006, 54:413-426.

23. Webb R, Garnsworthy PC, Gong JG, Armstrong DG: Control of follicular growth: local interactions and nutritional influences. J Anim Sci 2004, 82(Suppl):E63-E74

24. Sarkar M, Schilffarth S, Schams D, Meyer HH, Berisha B: The expression of leptin and its receptor during different physiological stages in the bovine ovary. Mol Reprod Dev 2010, 77:174-181.
25. Kikuchi N, Andoh K, Abe Y, Yamada K, Mizunuma H, Ibuki Y: Inhibitory action of leptin on early follicular growth differs in immature and adult female mice. Biol Reprod 2001, 65:66-71.

26. Duggal PS, Van Der Hoek KH, Milner CR, Ryan NK, Armstrong DT, Magoffin DA, Norman RJ: The in vivo and in vitro effects of exogenous leptin on ovulation in the rat. Endocrinology 2000, 141:1971-1976.

27. Ruiz-Cortés ZT, Men T, Palin MF, Downey BR, Lacroix DA, Murphy BD: Porcine leptin receptor: molecular structure and expression in the ovary. Mol Reprod Dev 2000, 56:465-474.

28. Nicklin LT, Robinson RS, Marsters P, Campbell BK, Mann GE, Hunter MG: Leptin in the bovine corpus luteum: receptor expression and effects on progesterone production. Mol Reprod Dev 2007, 74:724-729.

29. Burt Solorzano CM, McCartney CR: Obesity and the pubertal transition in girls and boys. Reproduction 2010, 140:399-410.

30. Chen YH, Lee MJ, Chang HH, Hung PF, Kao YH: 17 beta-estradiol stimulates resistin gene expression in $3 \mathrm{~T} 3-\mathrm{L} 1$ adipocytes via the estrogen receptor, extracellularly regulated kinase, and CCAAT/ enhancer binding protein-alpha pathways. Endocrinology 2006, 147:4496-4504

31. Ling $\mathrm{C}$, Kindblom J, Wennbo $\mathrm{H}$, Billig $\mathrm{H}$ : Increased resistin expression in the adipose tissue of male prolactin transgenic mice and in male mice with elevated androgen levels. FEBS Lett 2001, 507:147-150.

32. Delhanty PJ, Mesotten D, McDougall F, Baxter RC: Growth hormone rapidly induces resistin gene expression in white adipose tissue of spontaneous dwarf (SDR) rats. Endocrinology 2002, 143:2445-2448.

33. Li M, Fisette A, Zhao XY, Deng JY, Mi J, Cianflone K: Serum resistin correlates with central obesity but weakly with insulin resistance in Chinese children and adolescents. Int J Obes (Lond) 2009, 33:424-439.

34. Dai MH, Xia T, Chen XD, Gan L, Feng SQ, Qiu H, Peng Y, Yang ZQ: Cloning and characterization of porcine resistin gene. Domest Anim Endocrinol 2006, 30:88-97.

35. Abbott DH, Dumesic DA, Francs S: Developmental origin of polycystic ovary syndrome - a hypothesis. J Endocrinol 2002, 174:1-5

36. West C, Foster DL, Evans NP, Robinson J, Padmanabhan V: Intra-follicula activin availability is altered in prenatally-androgenized lambs. Mol Cell Endocrinol 2001, 185:51-59.

37. Foecking EM, Levine JE: Effects of experimental hyperandrogenemia on the female rat reproductive axis: suppression of progesterone-receptor messenger RNA expression in the brain and blockade of luteinizing hormone surges. Gend Med 2005, 2:155-165.

38. Sullivan SD, Moenter SM: Prenatal androgens alter GABAergic drive to gonadotropin-releasing hormone neurons: implications for a common fertility disorder. Proc Natl Acad Sci U S A 2004, 101:7129-7134.

doi:10.1186/1477-7827-11-45

Cite this article as: Rak-Mardyła et al:: Effects of resistin on porcine ovarian follicle steroidogenesis in prepubertal animals: an in vitro study. Reproductive Biology and Endocrinology 2013 11:45.

\section{Submit your next manuscript to BioMed Central and take full advantage of:}

- Convenient online submission

- Thorough peer review

- No space constraints or color figure charges

- Immediate publication on acceptance

- Inclusion in PubMed, CAS, Scopus and Google Scholar

- Research which is freely available for redistribution 